Iraqi Journal of Veterinary Sciences

\title{
Seroprevalence of Neospora caninum infections in cattle in Kirkuk province
}

\author{
M.Y. Nooruldeen ${ }^{\circledR}$, S.E. Jaafar ${ }^{\circledR}$ and A.I. Salih $\mathbb{C}$ \\ Medical Laboratory Technique Department, Technical College, Northern Technical University, Kirkuk, Iraq
}

Article information

Article history:

Received March 22, 2020

Accepted July 9, 2020

Available online March 15, 2021

\begin{tabular}{l}
\hline Keywords: \\
ELISA \\
Seroprevalence \\
Neospora caninum \\
Cattle \\
Kirkuk city \\
\hline
\end{tabular}

Correspondence:

M.Y. Nooruldeen

mohammedyawoz@ntu.edu.iq

\begin{abstract}
Neospora caninum was identified as a coccidian parasite as in 1988 , before that date it was misclassified as Toxoplasma gondii based on structural similarities. The aim of this study was to determine the seroprevalence of $N$. caninum in cattle in Kirkuk Province. A total of 185 cattle serum samples were collected randomly. Data about ages, gender and abortion history of females were recorded. Serum samples were examined by using ELISA as a screening test for the detection of anti- $N$. caninum IgG antibodies of past infection. Results showed that 53 (28.6\%) cattle were seropositive infected, with significantly higher seropositive infection of age group > 2 years in comparison to other age groups $94.3 \%$. The distribution of $N$. caninum of total infected cattle showed that the seropositive infection in females were $47(88.7 \%)$, which was more than males $6(11.3 \%)$ with a highly significant difference. There were $22(48.8 \%$ ) aborted cattle out of 47 infected cattle with $N$. caninum with no significant difference in comparison with the healthy group.
\end{abstract}

DOI: 10.33899/ijvs.2020.126832.1394, C2021, College of Veterinary Medicine, University of Mosul.

This is an open access article under the CC BY 4.0 license (http://creativecommons.org/licenses/by/4.0/).

\section{Introduction}

Neospora caninum is a protozoa coccidian parasite, obligatory intracellularly (order Eucoccidiorida, suborder Eimeriorina, and family Sarcocystidae), identified by Bjerkas at 1984 and causes abortion in cattle and dogs with neuromuscular disorder, and cattle are its major intermediate host (1-3). In both milk and beef cattle, N. caninum is a cause of abortion. Cows of any age will abort their pregnancy from 3 months of gestation to term and most induced neosporosis abortions occur at a gestation of 5-6 months. Fetuses may die in utero and resorbed, stillborn, wrinkled, autolysis, born alive with clinical signs or born clinically healthy but chronically infected. Epidemic or endemic abortions may occur in neosporosis (4). Neosporosis is the leading cause of reproductive failure in many countries with significant economic losses (5). Neospora congenital transmissions can often happen in the same animal. In livestock, fetal deaths in utero, mummification and birth of infected calves can occur with or without clinical signs. Dairy and beef cattle are also reported reductions in milk yield and underweight calves (6). Infected dogs in their feces excrete oocysts that are then ingested by intermediate hosts such as horses, goats, sheep and water buffaloes. (7).

There is no data available on prevalence of $N$. caninum in cattle in Kirkuk province. The aim of this study was to determine the seroprevalence of $N$. caninum infections in Kirkuk at the north part of Iraq.

\section{Materials and methods}

This study was conducted from 1st September 2018 to $15^{\text {th }}$ October 2019 on 185 randomly chosen cattle from which blood samples were collected by means of disposable syringes. Data about the ages, sex and history of abortion in females were recorded. All specimens were taken to the laboratory immediately. Serum was separated by centrifugation in $1000 \mathrm{xg}$ for $10 \mathrm{~min}$. All serum samples were equally divided into two micro-tubes and stored before laboratory testing at $-20^{\circ} \mathrm{C}$. 
Serum samples were tested by using ELISA (Bio-X Diagnostics) for detection of anti $N$. caninum ( $\operatorname{IgG}$ ) antibodies. Absorbance values above the cut-off level of 0.50 were considered as a positive result. This ELISA test was recorded on sensitivity and specificity $100 \%$ and $93 \%$, respectively. The predictive values of the test were $93.75 \%$ positive and $100 \%$ negative according to the instructions of the manufacturer (Bio-X Diagnostics).

\section{Statistical analysis}

Data analysis was done using SPSS Vr.24 program, and t-test and Mont Carlo test (MCP) were used at 5\% and $1 \%$ levels of significance.

\section{Results}

The number of examined age group $>2$ years was more (144) and significantly higher seropositive than others age groups $(94.3 \%)$ (Table 1). The distribution of Neospora infections according to sex demonstrated that the seropositivity in females $47(88.7 \%)$ were more than males $6(11.3 \%)$, with a highly significant difference (Table 2). There were 22(48.8\%) aborted cattle out of 47 seropositive cattle with Neospora caninum with no significant difference in comparison with healthy control (Table 3).

Table 1: Allocation of $N$. caninum $\operatorname{IgG}$ in examined groups according to age

\begin{tabular}{lccccc}
\hline \multirow{2}{*}{ Age group (year) } & \multicolumn{2}{c}{ No. of examined cattle } & \multicolumn{2}{c}{ N. caninum-IgG positive } & \multirow{2}{*}{ P value } \\
\cline { 2 - 5 } & Count & $\%$ & Count & $\%$ & \\
\cline { 2 - 5 } & 19 & 10.3 & 1 & 1.9 & 0.02 Significant \\
$1-2$ & 22 & 11.9 & 2 & 3.8 & P value $<0.05$ \\
$>2$ & 144 & 77.8 & 50 & 94.3 & \\
\hline Total & 185 & 100 & 53 & 100 & \\
\hline
\end{tabular}

Table 2: incidence of $N$. caninum $\mathrm{IgG}$ in examined groups according to the sex

\begin{tabular}{lccccccc}
\hline \multirow{2}{*}{ Gender } & \multicolumn{2}{c}{ No. of examined cattle } & \multicolumn{2}{c}{ N. caninum-IgG positive } & \multicolumn{2}{c}{ N. caninum-IgG negative } & \multirow{2}{*}{ P value } \\
\cline { 2 - 6 } & Count & $\%$ & Count & $\%$ & Count & $\%$ & 0.001 \\
Male & 16 & 8.6 & 6 & 11.3 & 10 & 7.6 & Highly significant \\
Female & 169 & 91.4 & 47 & 88.7 & 122 & 92.4 & P value $<0.05$ \\
\hline Total & 185 & 100 & 53 & 100 & 132 & 100 & \\
\hline
\end{tabular}

Table 3: The aborted cattle among the positive females infected with $N$. caninum

\begin{tabular}{|c|c|c|c|c|c|}
\hline \multirow{2}{*}{\multicolumn{2}{|c|}{ Anti- Neospora Antibodies IgG }} & \multicolumn{3}{|c|}{ Studied groups } & \multirow{2}{*}{$\begin{array}{c}\text { Chi-Square } \\
\text { (P-value) }\end{array}$} \\
\hline & & Control & Abortion & Non abortion & \\
\hline \multirow{2}{*}{ Negative } & $\mathrm{N}$ & 122 & 0 & 0 & \multirow{6}{*}{$\begin{array}{c}0.1 \\
\text { Non-significant }\end{array}$} \\
\hline & $\%$ & $100.0 \%$ & $0.00 \%$ & $0.00 \%$ & \\
\hline \multirow{2}{*}{ Positive } & $\mathrm{N}$ & 0 & 22 & 25 & \\
\hline & $\%$ & $0.00 \%$ & $48.8 \%$ & $51.2 \%$ & \\
\hline \multirow{2}{*}{ Total } & $\mathrm{N}$ & 122 & 22 & 25 & \\
\hline & $\%$ & $100.0 \%$ & $48.8 \%$ & $51.2 \%$ & \\
\hline
\end{tabular}

\section{Discussion}

Neospora caninum is seen as one of the world's most significant causes of abortion in the cattle. There are reports of infection in other animals including sheep, goat, deer and horse (8). Yearly, economic loss due to neosporosis in Australia in beef and dairy cattle is considered 25 and 85 million respectively. The estimation for New Zealand in dairy cattle is 17.8 million. According to Dubey, the loss for California is 35 million but the real economic loss should be more than this estimation $(9,10)$. A study in Iraq on Buffaloes was performed and found about $20 \%$ prevalence of $N$. caninum (7). The prevalence of $N$. caninum was $17.5 \%$ in dairy and beef cattle in other Iraqi provinces (8). This result was the first investigation of $N$. caninum among Iraqi cattle in Kirkuk, which indicated that the parasite is present, and at a high level with percentage of $28.6 \%$. The seroprevalence of $28.6 \%$ is the highest compared to international studies which reported the seroprevalences of $N$. caninum in cattle between $2.8-50 \%$ (11-17). However, found the lowest level in cattle between $32-44.4 \%(10,18)$, while in another study, the overall prevalence of $N$. caninum infection was $46.9 \%$ (19). Perhaps the difference is due to the geographical area or the surrounding environment and 
topographical reasons that affect the development and survival of oocysts (20). Many factors may affect the seroprevalence of parasites including sample size, environmental differences age and breed of cattle $(21,22)$. Infectious materials, like fetuses prone to miscarriage, dead calves and fetal membranes can be essential sources of dogs infected. Thus, the high seroprevalence of neosporosis could be linked to the appearance on the dairy farm of many stray and domestic dogs noticed at the time of the study in Kirkuk city, management systems are also noted to affect breed seroprevalence more than breed related susceptibility to infection (23). The results revealed that females cattle were most infected than males with $N$. caninum, this is what was explained by Olmo et al. (24), who reported that females were most infected dairy cattle than males. Also about 22 $(48.8 \%)$ of infected cattle out of 45 have positive cases with $N$. caninum. Another study reported the most of the injuries that occur in cattle are in females because, tachyziote can penetrate the placenta and cause necrosis of the placental membrane of the cow and causes early miscarriage (25).

\section{Conclusions}

According to this study, there are highly $N$. caninum infections among cattle in Kirkuk province and the females are more susceptible to infection than the males. Further studies are warranted to investigate the distribution of $N$. caninum including high female and male cattle number. The study also revealed that the abortion in the cows is a major consequence of $N$. caninum infections which need more investigation of this criterion.

\section{Acknowledgments}

We would like to acknowledge all veterinary staff and animal owners for their assistance and facility during animal handling and sample collection.

\section{Conflict of interest}

The authors declared that there is no conflict of interest.

\section{References}

1. Borsuka S, Andreotti R, Leivas LF. Development of an indirect ELISANcSRS2 for detection of Neospora caninum antibodies in cattle. Vet Parasitol. 2011;177:33-38. DOI: 10.1016/j.vetpar.2010.11.026

2. Almeria S, Lopez-Gatius F, Garcia-Ispierto I, Nogareda C, Bech-Sàbat G, Serrano B, Santolaria P, Yániz JL. Effects of crossbreed pregnancies on the abortion risk of Neospora caninum-infected dairy cows. Vet Parasitol. 2009;163:323-329. DOI: 10.1016/j.vetpar.2009.04.026

3. Piagentini M, Moya-Araujo CF, Prestes NC, Sartor IF. Neospora caninum infection dynamics in dairy cattle. Parasitol Res. 2012;111:717-721. DOI: $10.1007 / \mathrm{s} 00436-012-2891-0$

4. Arreola-Camberos S, Garcia-Marquez LJ, Macedo-Barragan R, Morales-Salinas E, Figueroa-Chavez D. Risk factors and seroprevalence against Neospora caninum in Dual-purpose and beef cattle in Colima, Mexico. J Anim Vet Adv. 2012;11(14):2440-2444. DOI: $10.3923 /$ javaa.2012.2440.2444

5. Wang X, Song X, Yang J, Liu Q, Liu J. Characterization of Neospora caninum microneme protein 26 and its potential use as a diagnostic marker for neosporosis in cattle. Front Vet Sci. 2020;7:357. 10.3389/fvets.2020.00357

6. More G, Bacigalupe D, Basso W, Rambeaud M, Beltrame F, Ramirez B, Venturini MC, Venturini L. Frequency of horizontal and vertical transmission for Sarcocystis cruzi and Neospora caninum in dairy cattle. Vet Parasitol. 2009;160:51-54. DOI: 10.1016/j.vetpar.2008.10.081

7. Al-amery A, Faraj A, Faleh I. Seroprevalence and histopathological study of neosporosis in water buffaloes (Bubalus bubalis) in Baghdad city, Iraq. J Anim Hlth Prod. 2016;(4)3:101-104. DOI: 10.14737/journal.jahp/2016/4.3.101.104

8. Mallah MO, Dawood KhA, Alrodhan MA. Seroepidemiological study for the prevalence of Neospora caninum in dairy and beef and cattle in some Iraqi provinces. Al-Qadisiya J Vet Med Sci. 2012;11(1):103-110. DOI: $\underline{10.29079 / \text { vol11iss1art177 }}$

9. Dubey JP, Schares G, Ortega-Mora LM. Epidemiology and control of neosporosis and Neospora caninum. Clin Microbiol Rev. 2007;20:323367. DOI: 10.1128/CMR.00031-06

10. Noori M, Rasekh M, Ganjali M, Nourollahi FS. Seroprevalence of Neospora caninum infection and associated risk factors in cattle of Sistan Areas, southeastern Iran in 2016. Iranian J Parasitol. 2019;14(2);340-6. DOI: 10.18502/ijpa.v14i2.1149

11. Damriyasa IM, Schares G, Bauer C. Seroprevalence of antibodies to Neospora caninum in Bosjavanicus ('Bali cattle') from Indonesia. Trop Anim Health Prod. 2010;42:95-98. DOI: 10.1007/s11250-009-9390-z

12. Sengupta PP, Balumahendiran M, Raghavendra AG, Honnappa TG, Gajendragad MR, Prabhudas K. Prevalence of Neospora caninum antibodies in dairy cattle and water buffaloes and associated abortions in the plateau of Southern Peninsular India. Trop Anim Hlth Prod. 2013;45:205-210. DOI: 10.1007/s11250-012-0192-3

13. Hussien MO, El-Fahal AM, Enan K, Mohammed S, Ibrahim A, Taha KM, Elhussein AM. Seroprevalence of Neospora caninum in cattle in Sudan. Vet World. 2012;5(8):465-468. DOI: 10.5455/vetworld

14. Yagoob G. Seroepidemiology of Neospora caninum in cattle in EastAzerbaijan province, North West Iran. J Anim Vet Adv. 2012;11(5):645-648. DOI: 10.3923/javaa.2012.645.648

15. Waladjo AR, Gbati OB, Kone P, Lapo RA, Chatagnon G, Bakou SN, Pangui LJ, Diop PE, Akakpo JA, Tainturier D. Seroprevalence of Neospora caninum antibodies and its consequences for reproductive parameters in dairy cows from Dakar-Senegal, West Africa. Trop Anim Health Prod. 2010;42:953-959. DOI: 10.1007/s11250-009-9513-6

16. Santos SL, Costa KS, Gondim LQ, Silva MS, Uzêda RS, Abe-Sandes K, Gondim LF. Investigation of Neospora caninum, Hammondia sp., and Toxoplasma gondii in tissues from slaughtered beef cattle in Bahia, Brazil. Parasitol Res. 2010;106:457-461. DOI: 10.1007/s00436-009$\underline{1686-4}$

17. Llanoa H, Guimarãesb M, Soaresa R, Silvac G. Seroprevalence and risk factors for Neospora caninum infection in cattle from the eastern Antioquia, Colombia. Vet Anim Sci. 2018;6:69-74. 10.1016/j.vas.2018.03.001

18. Ibrahim AM, Elfahal AM, El Hussein AM. First report of Neospora caninum infection in cattle in Sudan. Trop Anim Hlth Prod. 2012;44:769-772. DOI: 10.1007/s11250-011-9963-5

19. Inpankaew T, Jittapalapong S, Mitchell THJ, Sununta Ch, Igarashi I, Xuan X. Seroprevalence of Neospora caninum infection in dairy cows in Northern provinces, Thailand. Acta Parasitol. 2014;59(2):305-309. DOI: $10.2478 / \mathrm{s} 11686-014-0245-\mathrm{Z}$

20. Alseady HH, Kawan MH. Prevalence and molecular identification of Cryptosporidium spp in cattle in Baghdad province, Iraq. Iraqi J Vet Sci. 2019;33(2):389-394. DOI: 10.33899/ijvs.2019.163084

21. Nasira A, Lanyona SR, Schares G, Anderson ML, Reichel MP. Seroprevalence of Neospora caninum and Besnoitia besnoiti in south Australian beef and dairy cattle. Vet Parasitol. 2012;186:480-485. DOI: $\underline{10.1016 / \text { j.vetpar.2011.11.032 }}$ 
22. Sakban FM and A'aiz NN. Investigate the Toxoplasma gondii infection in the consumed beef in Al-Diwaniyah province. Iraqi $\mathrm{J}$ Vet Sci. 2020;34(1):95-99. DOI: 10.33899/ijvs.2020.164336

23. Silva RC, and Machado GP. Canine neosporosis: Perspectives on pathogenesis and management. Vet Med J. 2016;7:59-70. DOI: 10.2147/VMRR.S76969

24. Olmo L, Reichel MP, Nampanya S, Khounsy S, Wahl LC, Clark BA, Thomson PC, Windsor PA, Bush RD. Risk factors for Neospora caninum, bovine viral diarrhoea virus, and Leptospira interrogans serovar Hardjo infection in smallholder cattle and buffalo in Lao PDR. PLoS ONE. 2019;14(8):1-25. DOI: 10.1371/journal.pone.0220335

25. Jiménez-Pelayo L, García-Sánchez M, Vázquez P, Regidor-Cerrillo J, Horcajo P, Collantes-Fernández E, Blanco-Murcia J, GutiérrezExpósito D, Román-Trufero A, Osoro K, Benavides J, Ortega-Mora LM. Early Neospora caninum infection dynamics in cattle after inoculation at mid-gestation with high (Nc-Spain7)- or low (NcSpain1H)-virulence isolates. Vet Res. 2019:50-72. DOI: 10.1186/s13567-019-0691-6

\section{الانتشار المصلي لعدوى Neospora caninum في الأبقار في محافظة كركوك لوك}

\author{
محمد ياوز نورالدين ' شاهين اكرام جعفر و عبد المنعم إبراهيم \\ صالح' - معاوز
}

قسم تقنيات المختبر ات الطبية، الكلية التقنية، الجامعة التقنية الثمالية،

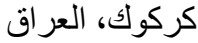

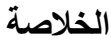

تم تصنيف البوغية الكلبية N. caninum من ضمن الطفيليات



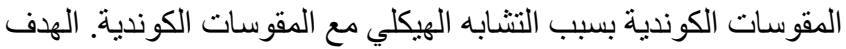

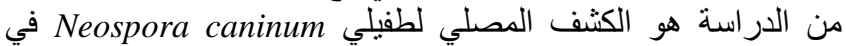

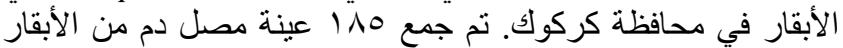
بشكل عثوائي، وتم تسجيل جميع المعلومات حول حول جنس و وأعمار الأبقار

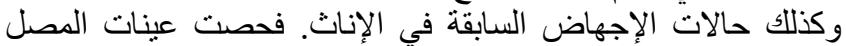

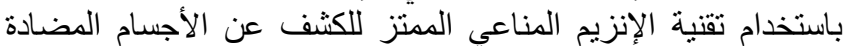

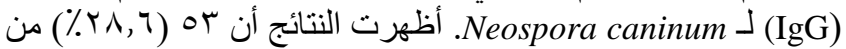

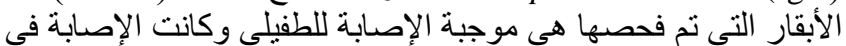

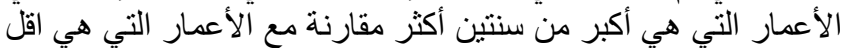

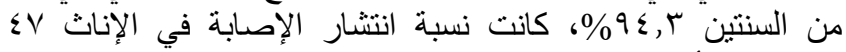



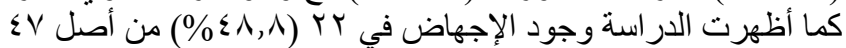

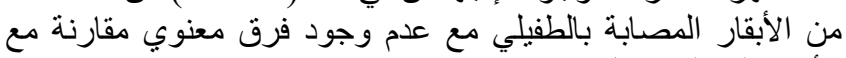
الأبقار التي لم تسجل فيها الإصـابة. 